\title{
PENINGKATAN PEMAHAMAN APARATUR DESA DALAM PERANCANGAN PEMBUATAN PERATURAN DESA DI DESA GALANTI KABUPATEN BUTON
}

\author{
IK Dewi, Edy Nurcahyo ${ }^{1)}$ \\ Fakultas Hukum, Universitas Muhammadiyah Buton, Indonesia \\ J1. Betoambari, No. 36 Kota Baubau 93721 \\ E-mail: indahkusumamh@gmail.com,
}

\begin{abstract}
Abstrak
Pengabdian masyarakat yang bertujuan untuk meningkatkan pemahaman dan keterampilan dalam membuat peraturan desa di Desa Galanti. Pengabdian telah dilaksanakan pada bulan Januari sampai bulan Maret 2019. Metode yang digunakan yaitu workshop dan pelatihan tentang penyusunan peraturan desa. Kegiatan worksop tersebut diikuti oleh aparatur pemerintahan desa, Badan Permusyawarahan Desa (BPD) dan juga tokoh adat di Desa Galanti. Kerangka struktur Peraturan Desa sebagai berikut: Penamaan/Judul; Pembukaan; Batang Tubuh; Penutup; dan Lampiran bila diperlukan. Hasil dari pengabdian adalah draf rancangan Peraturan Desa.
\end{abstract}

Kata Kunci: Pemahaman Aparatur, Perancangan, Peraturan Desa

\section{A. Pendahuluan}

Kabupaten Buton merupakan satu daerah tingkat II di Provinsi Sulawesi Tenggara, Indonesia. Kabupaten Buton terletak di Pulau Buton yang merupakan pulau terbesar di luar pulau induk Kepulauan Sulawesi, yang menjadikannya pulau ke 113 terbesar di dunia. Ibukota kabupaten ini terletak di Pasar Wajo. Kabupaten ini memiliki luas wilayah 2.488,71 $\mathrm{km}^{2}$ (sebelum pemekaran $6.463 \mathrm{~km}^{2}$ ) dan pada tahun 2004 berpenduduk sebanyak 265.724 jiwa (sebelum pemekaran 533.931 jiwa). Kabupaten Buton terkenal sebagai penghasil aspal.

Sebagai sebuah daerah otonom, Kabupaten Buton memiliki wilayah administrasi yang terdiri dari 7 (tujuh) kecamatan yaitu Kecamatan Pasar Wajo, Kecamatan Wabula, Kecamatan Wolowa, Kecamatan Siontapina, Kecamatan Lasalimu Selatan, Kecamatan Lasalimu, Kecamatan Kapontori. Dari wilayah administrasi yang terbagi dalam beberapa kecamatan, juga terdapat wilayah adminitrasi yang lebih kecil lagi, yatu desa yang terikat pada Undang-Undang No. 6 Tahun 2015 tentang Desa. Sebagaimana ketentuan dalam UU Desa serta selaras dengan Nawa Cita Pemerintah Pusat, kebijakan strategis untuk 
membangun bangsa melalui desa salah satu kebijakannya adalah dengan mengoptimalkan potensi desa melalui Peraturan Desa (Perdes) disetiap desa. Persoalan yang muncul jika dikaitkan dengan kondisi desa yang ada di Kabupaten Buton sampai pada tahun 2018, masih terdapat desa yang belum memiliki Peraturan Desa (Perdes) sebagai (1) Pedoman kerja bagi semua pihak dalam penyelenggaran kegiatan di desa; (2) Sarana terciptanya kehidupan yang serasi, selaras, dan seimbang di desa; (3) sarana memudahkan tercapainya tujuan; (4) sarana acuan dalam rangka pengendalian dan pengawasan; (5) Dasar pengenaan sanksi dan hukuman; (6) Sarana mengurangi terjadinya penyimpangan atau kesalahan dalam pengelolaan pemerintahan desa. Salah satu desa yang belum memiliki Peraturan Desa (Perdes) adalah Desa Galanti yang merupakan salah satu wilayah administrasi Kecamatan Wolowa.

\section{B. Masalah}

Dalam sejumlah observasi yang dilakukan pada beberapa desa di Kecamatan Wolowa, maka perumusan masalah yang ditemukan adalah sebagai berikut: (1) Belum adanya Peraturan Desa di Desa Galanti Kecamatan Wolowa sehingga pengetahuan masyarakat untuk memetakan potensi desa yang dapat menjadi sarana penggerak inovasi di desa belum optimal; (2) Belum optimalnya sosialisasi kepada masyarakat perihal program desa inovasi berbasis potensi yang ada di desa; (3) Belum optimalnya kinerja lembaga masyarakat desa dalam berkolaborasi untuk membangun inovasi desa; (4) Dukungan sarana dan prasarana desa belum optimal di gunakan oleh sebab pengetahuan masyarakat masih minim; (5) Program pembangunan dan pemberdayaan masyarakat yang dilaksanakan oleh Pemerintah Daerah kabupaten Buton, belum memperhatikan kondisi potensi desa.

\section{Metode Pelaksanaan}

Pengabdian masyarakat ini dilaksanakan menggunakan metode pemetaan potensi dan penguatan kapasitas, melalui 5 indikator inovasi desa. Diharapkan dari pengabdian ini dapat memberikan deskripsi potensi dan langkah-langkah yang dapat dilaksanakan oleh desa dalam memberdayakan masyarakatnya guna peningkatan ekonomi desa berbasis potensi. Dalam pelaksanaannya berdasarkan rangkaian tahapan yang secara umum adalah sebagai berikut:

1. Identifikasi potensi

Pelaksana bersama Pemerintah Desa mengidentifikasi potensi yang dimiliki Desa Wolowa Kecamatan Wolowa, yaitu jumlah dan potensi usaha ekonomi masyarakat, Potensi Pariwisata dan Potensi Sosial Budaya yang dapat dijadikan sebagai sumber ekonomi kreatif masyarakat. 


\section{Analisis Kebutuhan}

Dilakukan dengan menganalisis kebutuhan Desa berdasarkan indikator Peraturan Desa, untuk mencari solusi dari permasalahan. Memprioritaskan kebutuhan Desa yang paling mendesak disesuaikan dengan kemampuan Pelaksana dan Pemerintah desa saat itu. Analisis Kebutuhan yang dilakukan meliputi: (a) Potensi Ekonomi Desa; (b) Sumberdaya Manusia Terampil di Desa; (c) Dukungan Sarana dan Prasarana Ekonomi di Desa; (d) Kelembagaan Masyarakat Desa; (e) Dukungan Kebijakan dan Program Pemerintah.

3. Rencana Kerja

Setelah menganalisis kebutuhan di tiap desa, kemudian membuat analisis kebutuhan dan solusinya, maka tahap selanjutnya adalah pelaksanaan kegiatan berdasarkan prioritas yang akan disesuaikan dengan jadwal pelaksanaan pendampingan.

4. Evaluasi Kegiatan

Evaluasi tiap program akan dilakukan sepanjang pelaksanaan program berlangsung, dalam tahap ini Pelaksan juga memberikan kesempatan kepada Pemerintah Desa untuk secara bersama-sama melakukan evaluasi terhadap setiap kegiatan yang dilakukan.

Setelah dilakukan pemetaan potensi desa, metode yang digunakan untuk memberikan pemahamam dan keterampilan dalam pembuatan peraturan desa yaitu dengan memberikan penyuluhan dan pelatihan melalui workshop.

\section{Pembahasan}

Berdasarkan permasalah tersebut di atas, solusi untuk memberikan penyelesaian terhadap permasalahan yang dihapadapi oleh desa galanti yaitu dengan pengabdian masyarakat dengan judu "Peningkatan Pemahaman Aparatur Desa dalam Perencanaan Pembuatan Peraturan Desa di Desa Galanti Kecamatan Wolowa kabupaten Buton" agar semua permasalahan yang telah diidentifikasi dapat diselesaiakan diantaranya adalah sebagai berikut: (1) Membantu dan membimbing aparatur desa galanti dalam pembuatan Peraturan Desa (Perdes); (2) Membantu sosialisasi pengoptimalan program desa kepada masyarakat; (3) Meberikan penyuluhan kepada masyarakat desa galanti akan pentingnya peraturan desa bagi masyarakat desa galanti

Peraturan Desa (Perdes) adalah peraturan-peraturan yang ditetapkan oleh Kepala Desa bersama Badan Permusyawaratan Desa (BPD), peraturan tersebut berlaku di wilayah desa tertentu. Peraturan Perundang-Undangan pada tingkat desa meliputi: (1) Peraturan Desa; (2) Peraturan Kepala Desa; (3) Keputusan Kepala Desa. 
Kerangka struktur Peraturan Desa, diantaranya adalah: (1) Penamaan/Judul; (2) Pembukaan; (3) Batang Tubuh; (4) Penutup; (5) Lampiran (Jika Dibutuhkan). Sementara itu, materi muatan Peraturan Desa adalah seluruh materi muatan dalam rangka penyelenggaraan pemerintahan desa, pembangunan desa, dan pemberdayaan masyarakat, dan juga penjabaran lebih lanjut dari ketentuan peraturan perundang-undangan yang lebih tinggi.
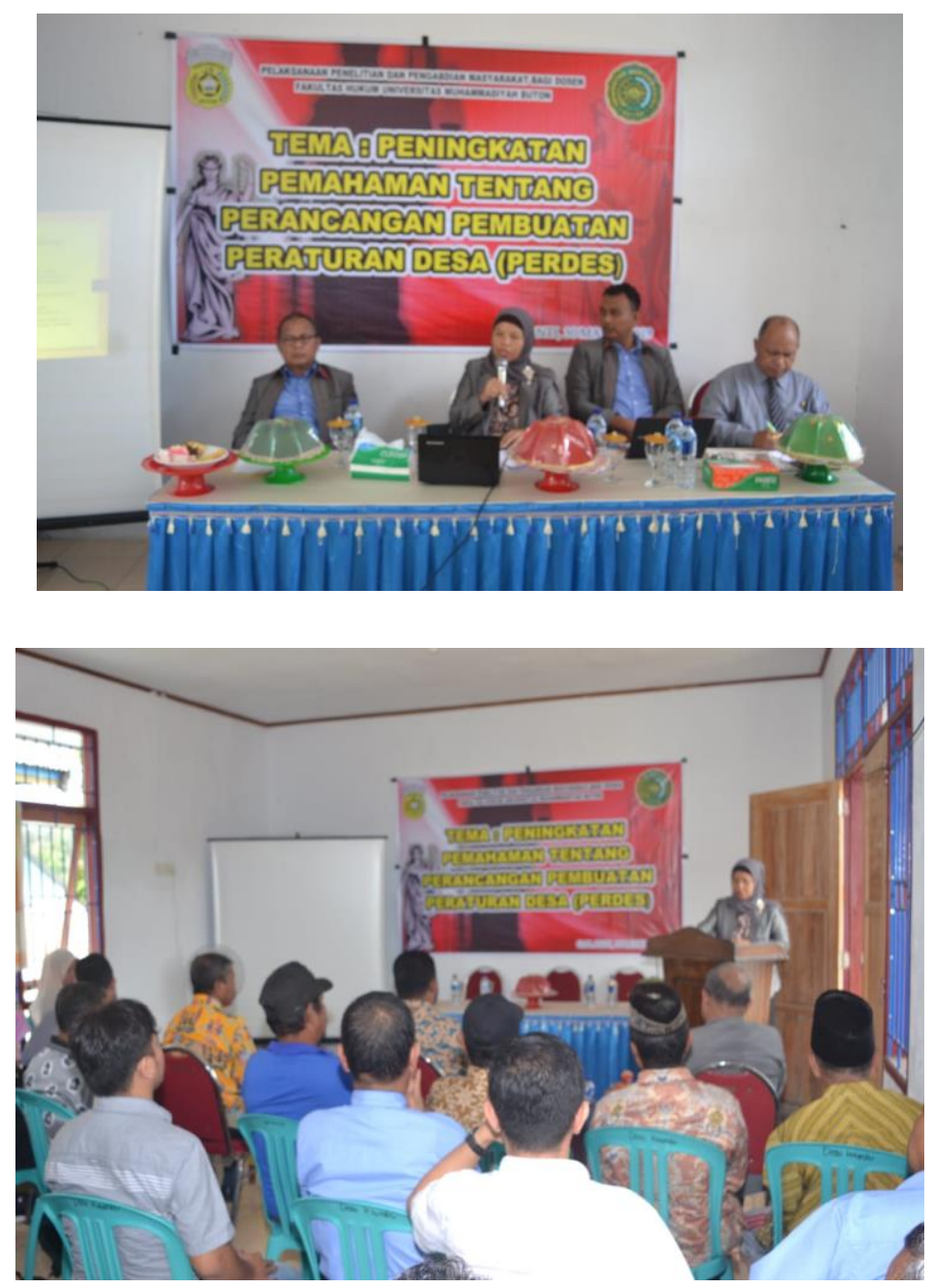

Gambar 1. Workshop Pembuatan Peraturan Desa (Perdes) di Desa Galanti

\section{E. Kesimpulan}

Peroblem Pembuatan Peraturan Desa (Perdes) di Desa Galanti selama ini terhambat oleh kurangnya Sumber Daya Manusia (SDM) yang ada pada Aparatur Pemeintahan Desa Galanti. Padahal banyak potensi desa yang bisa dikelola secara maksimal melalui instrument Peraturan Desa (Perdes), seperti Peraturan Desa yang mengatur pennggunaan dan pemanfaatan air bersih dan Peraturan Desa untuk pengendalian Ternak Lepas. Tidak adanya 
Perdes yang mengatur tentang dua contoh tersebut seringkali memunculkan perselisihan antar warga masyarakat. Dengan adanya program pengabdian masyarakat dengan judul "Peningkatan Pemahaman Aparatur Desa Dalam Perancangan Pembuatan Peraturan Desa Di Desa Galanti, Kabupaten Buton" memberikan solusi bagi segala permasalahan yang selama ini dihadapi oleh masyarakat desa galanti.

\section{DAFTAR PUSTAKA}

Astariani.LNG. (2019). Pelatihan Penyusunan Peraturan Desa di Desa Pemogan Kecamatan Denpasar Selatan.

Undang-Undang Nomor 6 Tahun 2014 Tentang Desa

Peraturan Pemerintah Nomor 43 Tahun 2014 tentang Peraturan Pelaksana Undang-Undang Nomor 6 Tahun 2014 tentang Desa

Peraturan Pemerintah RI Noor 47 Tahun 2015 tentang Perubahan atas Peraturan Pemerintah Nomor 43 Tahun 2014 tentang Peraturan Pelaksanaan Undang-Undang Nomor 6 Tahun 2014 tentang Desa

Peraturan Menteri Dalam Negeri Nomo 111 Tahun 2014 tentang Pedoman Teknis Peraturan di Desa 